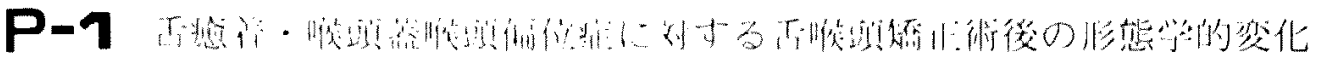

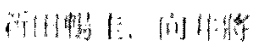

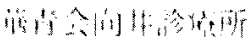

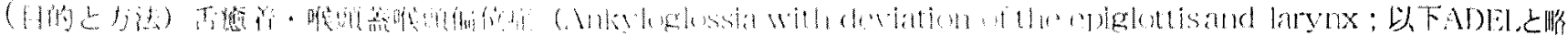

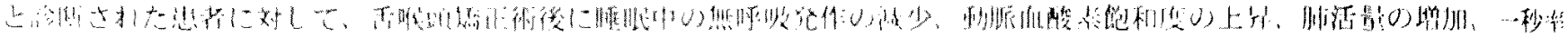

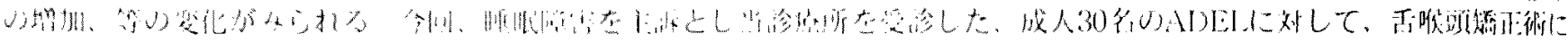

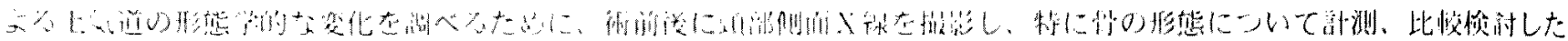

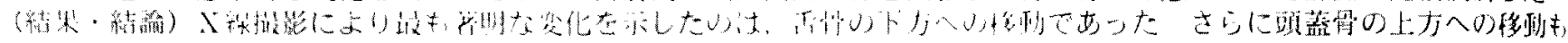

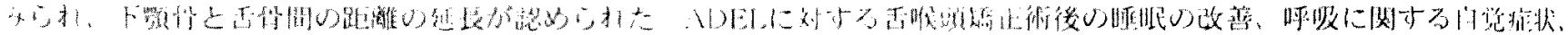

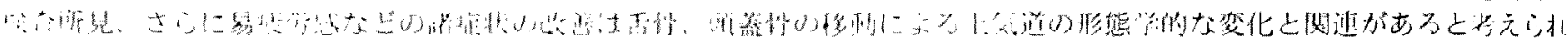

\title{
P-2 中父道アレルギー及びその類似拝例の検尉
}

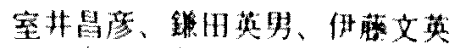

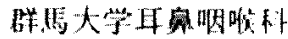

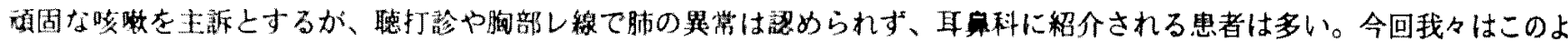

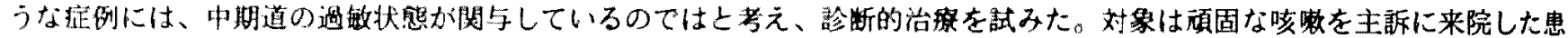

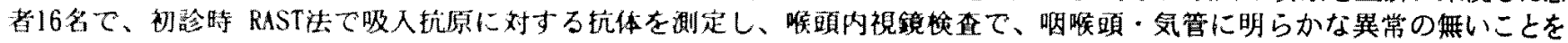

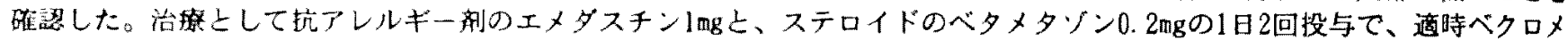

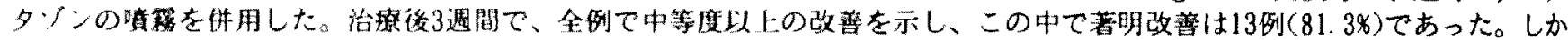

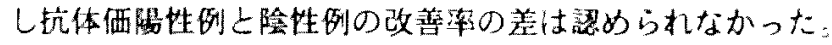

中気道の反応性の立進は、即時型アレルギーまたはアレルギー類似反応によると考えられた。また今まで報告された文献を参 考に中気道アレルギー・過敏症につき考察を加えた

P-3 耳崽咽喉科診璙における上咽頭炎の重要悱につついて

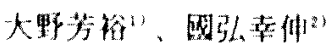

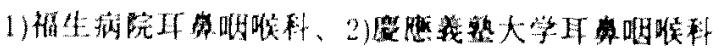

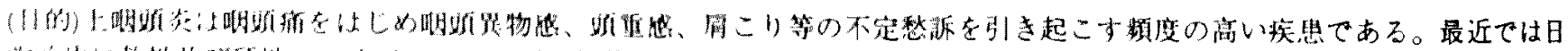

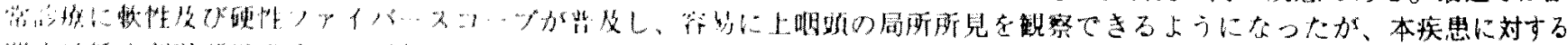

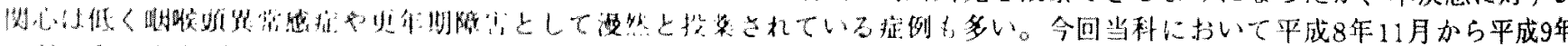

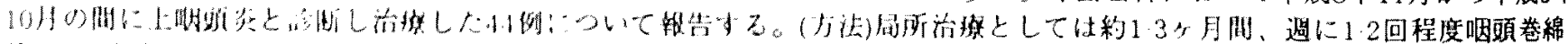

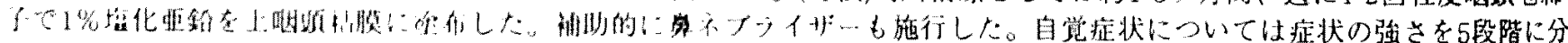

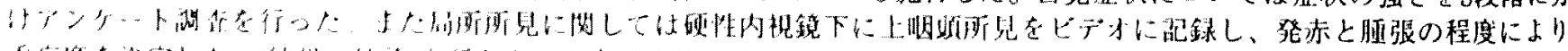

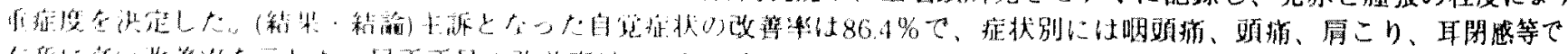

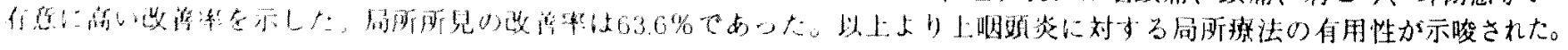

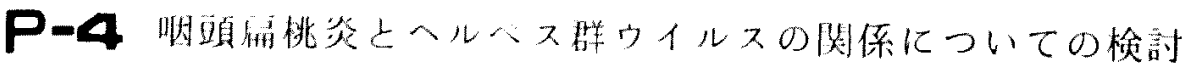

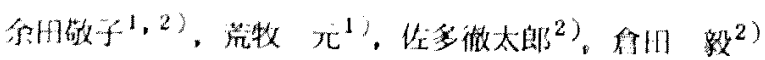

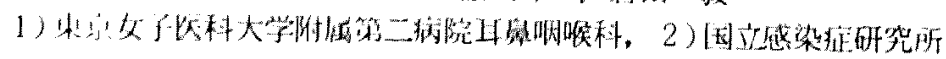

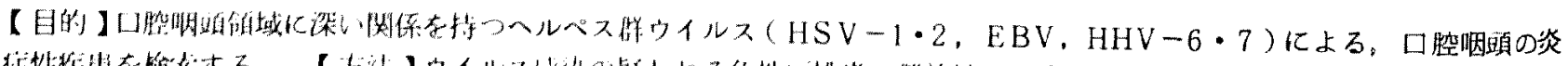

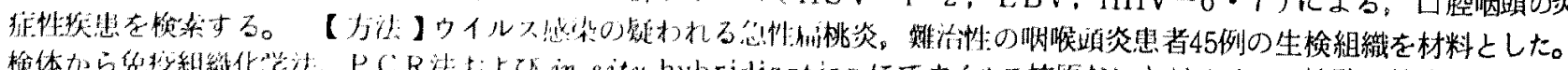

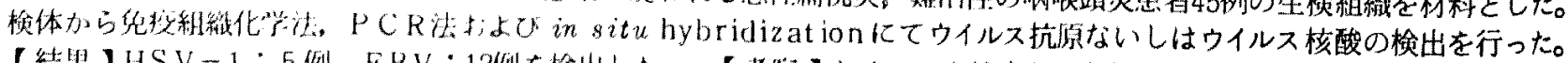

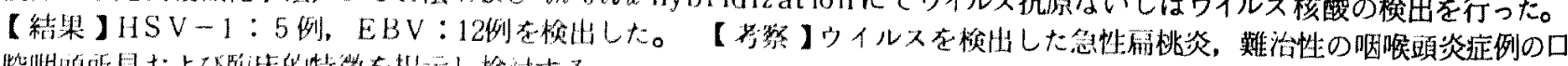

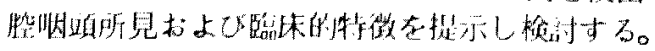

